\title{
Should educators promote homeschooling? Worldwide growth and learner outcomes
}

Brian Ray

Abstract: The purpose is to briefly summarize forty years of research on the learner outcomes of the modern homeschooling movement and address whether educators should be promoting home education. Studies show that homeschooling (home education) is generally associated with positive learner outcomes. On average, the home educated perform better than their institutional school peers in terms of academic achievement, social, emotional, and psychological development, and success into adulthood (including university). Certain pedagogical and familial elements that are systemic to freely chosen parent-led home-based private education homeschooling are may be the keys to the overall better performance and development of most children - not only the home educated - and into their lives as adults. If this is true, should professional educators be promoting homeschooling rather than criticizing it or trying to inhibit its growth? Are there certain categories of families for whom home education would not be a good idea? Is home education a pedagogical choice and approach about which educators should be skeptical and antagonistic or from which they can learn, be better informed about the needs and successes of students, and support according to the findings of empirical evidence?

Keywords: homeschooling, home education, learner outcomes, educational reform, academic achievement

\section{Introduction}

Homeschooling has been expanding and growing in numbers of children and families in nations around the world for the past 40 years. Historically, parent-led home-based education - homeschooling - was the norm for thousands of years but it became nearly extinct in most western nations by 
the 1970s. The resurgence in homeschooling has been led by families and a social movement in the United States where homeschooling exploded in population size during the 1990s. A form of the education of children and adolescents that once appeared to be gone forever or would only remain as a vestige of some ancient form of education became the talk of many newspapers, news sites, research journals, teachers' unions, state departments of education, and legislative bodies (e.g., New York Times, 2020; Solorzano, 1985).

After the 1990s, homeschooling then steadily grew in the United States from 2000 to 2020. From March of 2020 to March of 2021, however, during government lockdowns and restrictions due to concerns Covid-19, data show that homeschooling nearly doubled in the United States. That was a change from about 2.6 million homeschool students in grades $\mathrm{K}$ to 12 to roughly 5.0 million (Ray, 2021).

The significant global re-emergence of homeschooling has raised many questions. This is partially true because homeschooling, de facto, denies the essentiality of a professional class of educators, government control of teachers, the institutional nature of schooling, university professors of education who train people to be teachers, and the government's redistribution of wealth via taxation to support effective education. Some of the question raised over the past several decades follow:

1. Can persons who are not professionally trained as teachers effectively teach academics to children?

2. Can non-government-certified teachers successfully educate children?

3. Can adults of relatively low formal education levels offer academic and social educational opportunities to children that enable them to be successful adults?

4. Can parents of relatively low socio-economic status effectively educate their children?

5. What are the learner outcomes - such as academic achievement, social and emotional development, and success in adulthood - of homeschooling?

6. To what extent, if any, should the civil government control (regulate) private, parent-led home-based education?

7. If home-educated children are doing well during their school years and into adulthood, should educators promote homeschooling to families, communities, and nations?

8. Why do some educators, philosophers, and legal scholars oppose home education? 
A definition is necessary before proceeding in this treatise. With respect to homeschooling, "Parent-directed means the parents have deliberately chosen to take responsibility for the education of their children, controlling both the education process and the curriculum (course of study). Family-based means the center of educational gravity is the home, with other resources being secondary" (homeschoolingbackgrounder.com, 2020).

\section{Empirical Evidence About Homeschooling}

Multiple dozens of quantitative and qualitative studies have focused on homeschooling, and the number of studies around the world has arisen dramatically over the past ten years. Since the majority of research has been on the U.S. homeschool movement, such will be the focus in this article. However, research from other nations will be drawn in when feasible and where space permits.

\section{Homeschool Law, Population Sizes, and Growth Rates}

The growth of homeschooling in the United States has already been mentioned. It should be kept in mind, however, that precise and reliable numbers are difficult to obtain because every one of the 50 states and the District of Columbia has its own law (or no law) related to homeschooling and some state governments do not collect homeschool data.

Just as laws regarding homeschooling vary amongst the states in the United States, home-education laws vary widely around the globe. In some nations, homeschooling is not banned and homeschool families are required to notify the state (government) or register with the state about their educational choice. In some of the nations, or provinces within them, homeschool families are not required to have any contact with the state. In other nations, homeschooling is banned (i.e., illegalized). Certain organizations provide estimates of the homeschool population size in various nations (e.g., Home School Legal Defense Association (HSLDA), 2020; Wikipedia, 2020). It is difficult and time-consuming, however, to verify the validity and reliability of all of the references and data in any source of information like these.

One example is Poland. Wikipedia reported that there were about 14,000 homeschool children in 2017. HSLDA reported that there were over 6,000 homeschool families. And recently Marek Budajczak of Poland (2020) reported the following: 
During the past 10 years (literally from 2009-2019 - in 2009 legal rules were constructively changed). the number of elementary and secondary homeschooling students has been grown from at most four dozen cases up to 12,000 during the 2019-2020 school year (and this was officially stated by the Ministry of National Education).

If there were 1.5 school-age children per homeschool family, there is roughly a $67 \%$ difference across the range of the three estimates.

Another example is information on Canada provided from a legal defense organization:

For the past 15 years, the number of elementary and secondary homeschooling children has been growing by about $5 \%$ per year in Canada. The Canadian Centre for Home Education estimates that there were more than 100,000 homeschooled students during the 2019-2020 school year. (Stock, 2020)

One more example will suffice. A representative of a human rights and homeschool defense group reported the following regarding Bulgaria:

In the last 5 years, the number of children in primary and secondary education educated at home (or in the family) has increased by about $10 \%$ per year in Bulgaria. The Association for Home Education (AHE), estimates that in the 20192020 school year there were over 3,500 homeschooled students in school (i.e., in families). (Kostov, 2020)

From about March of 2020 to April of 2021, many more millions of children around the world were forced by government mandates related to the reported Covid-19 health situation to experience schooling at home (CBS News, 2020; UNICEF, 2020). Various terms have been used for this educational situation, such as crisis schooling at home, government schooling at home, and virtual public schooling at home. Most of the millions of families suddenly faced with their children not attending institutional schools, whether government-run or private, did not choose this educational environment. It was forced upon them. It appears now, however, that a significant portion of the parents and children are volitionally choosing homeschooling in preference over continued institutional schooling. Sound empirical evidence on this will likely not be widespread for another year, but some data are now available. 
The United States Census Bureau (2021) reported that the number of adults in households with homeschooled students doubled from February of 2020 to about February of 2021. Budajczak (2020) reported the following for Poland:

We at Instytut Educatio Domestica have received evidence from a few of the biggest schools co-operating with homeschooling families (and such cooperation is government-mandated in Poland) and we estimate that at the beginning of the 2020-2021 school year there was growth in total numbers of homeschool students by about $40 \%$ in the whole country, and the numbers are still rising as of mid-October 2020. Obviously it is the effect of Covid-19 conditions. Firstly, it revealed clearly that schools work badly not only in the distant education conditions but in their overall practice. Secondly, parents being afraid for their children's health for the near future decided to keep them at home to give them good education in the safe family environment.

And following is a report from Bulgaria:

There are strong indications that the number of children studying at home is growing by $2030 \%$ in the $2020-2021$ school year. Examples of information supporting this change are the growth of applications for membership in the Support Group in the last few years and the number of joint meetings organized by members and interactions in the group. There are also a growing number of homeschooled families who use "umbrella schools" based in the United States to certify knowledge and produce a completed class certificate that Bulgarian institutions recognize. We believe that a significant part of this growth will be due to government restrictions and reactions to the Covid 19 situation. (Kostov, 2020)

It is obvious that a significant increase in the number of home-educated occurred from the 2019-2020 school year to the 2020-2021 school year. What is not clear, however, is what portion of this growth in the homeschool population will persist into the next three to five years. Time will tell.

\section{Demographics and Other the Traits of Homeschool Families}

Various studies across 40 years have considered the demographic and other characteristics of homeschool families. Early studies (e.g., Wartes, 
1987; Mayberry, Knowles, \& Ray, 1995; Van Galen, 1991; Ray, 1990, 2000) found that families in the 1980s and 1990s in the U.S.A. were generally of median income and were disproportionately (a) two-parent, (b) with parents of somewhat higher-than-average educational attainment, (c) ethnically white, politically conservative, and (d) religiously Christian. Also, these homeschoolers tended to fall into two major categories, with "pedagogues" focusing on teaching approaches, while "ideologues" emphasized philosophical or religious reasons for their educational choice (Van Galen, 1991). Van Galen astutely pointed out, however, that this was an oversimplification regarding homeschool parents and their motivations and there could be variations on the two themes. The various traits of homeschool parents and children noticeably changed during the first decades of the twenty-first century.

During the past 20 years, the demographic variety among homeschool families has continued to increase. As of 2016, the United States Department of Education (2019) reported on a nationally representative sample. Forty-one percent of homeschool students were of ethnic minority background (i.e., not White/non-Hispanic). Some $21 \%$ of the students lived in "poor" households (i.e., with incomes below the federal government poverty threshold). Regarding the highest formal education level of the parents / guardians, $15 \%$ had less than high school, 16\% had a high school diploma or equivalent, $25 \%$ had vocational/technical training or some college, and $45 \%$ had a bachelor's or higher degree.

\section{Reasons and Motivations for Homeschooling}

The typologies of ideologues and pedagogues that Van Galen's (1991) described reflected her basic categories in that reasons centered around parents wanting to either provide different values and beliefs to children from the overall secular humanism, anti-Christian thinking, and perceived statism and socialism taught in the nation's public schools or to be able to offer children pedagogical approaches different from those that emphasized things such as normative methods, high levels of structure, schedules with bells ringing between class periods, top-down and teacher-directed instruction, conformism, professional-created textbook curriculums, and an industrial-society-based schooling approach (Gatto, 2001). Other scholars, however, noted that motivations for homeschooling might be deeper and more nuanced than what was apparent (e.g., Knowles, 1988 on the role of biography in parents' rationales and teaching methods for homeschooling).

The U.S. Department of Education (USDE) has conducted large nation- 
wide sampling and found that the five reasons (out of ten offered for selection) most selected by homeschool parents, and they could choose multiple reasons, in 1999 USDE (2001) were, in descending order of importance, can give child better education at home $(49 \%)$, religious reasons $(38 \%)$, poor learning environment at school (26\%), family reasons $(17 \%)$, and to develop character/morality (15\%). Over time, the USDE revised its methods. By roughly twenty years later (USDE 2019), the five reasons most selected showed both some similarities and differences as the list was concern about environment of other schools (80\%), desire to provide moral instruction $(67 \%)$, dissatisfaction with academic instruction at other schools (61\%), desire to provide religious instruction (51\%), and desire to provide a nontraditional approach to child's education (39\%). That is, the relative importance of reasons for homeschooling appears to shift over time within the U.S. population.

One should note, further, that quantitative studies do not capture all relevant information. For example, Fields-Smith and Kisura (2013) examined the narratives of black homeschoolers in Metro-Atlanta (Georgia) and MetroDC areas. They found that "[t]he phenomenon of increasing black home education represents a radical transformative act of self-determination, the likes of which have not been witnessed since the 1960s and '70s" (p. 118). The two scholars discovered "push-pull" factors that drove black families to exit conventional schools in favor of homeschooling their children. One push factor is the "culture of low expectations" (p. 279) of black, especially male, children in public schools.

Research shows that the reasons for homeschooling shift and vary over time in a homeschool population at large and in individual families (Resetar, 1990), and there is much more than what appears on the surface regarding why particular diverse groups and individual families engage in familybased education. Homeschooling has increasingly reached across the span of forty years and appeals to a wide assortment of parents and adolescents who come from diverse sociocultural backgrounds and who hold to vastly divergent worldviews.

\section{Learner Outcomes}

For about a century in the United States, close to $100 \%$ of students had been taught by professional teachers and government schooling systems for over a century in many nations and most observers assumed that parents were not capable of doing a good job of educating their children. In this mi- 
lieu, scholars began to address whether the renewed movement of parent-led education would be effective in terms of children's academic achievement, social, emotional, and psychological development, and sound functioning in adulthood.

Several reviews of research during the past decade have considered learner outcomes (e.g., Kunzman \& Gaither, 2020; Murphy 2012; Ray 2017a). This type of review often becomes lengthy and easily biased by the author regarding the topics selected, the synthesis of them by the reviewer, and commission of certain logical fallacies (e.g., Kunzman \& Gaither, 2020). To address some of these shortcomings, Ray (2017b) narrowed the selection process to include only and all peer-reviewed published studies from the early 1980s into 2017. This review will be relied upon here because of its succinctness and frugal presentation.

\section{Academic achievement}

The literature search (Ray 2017b) resulted in 14 peer-reviewed quantitative studies for inclusion on the topic of academic achievement as a learner outcome. Most of the studies included, as dependent variables, students' scores on standardized academic achievement tests. Various dependent variables included constructs such as literacy skills, reading, language, listening skills, math, social studies, and science scores on the achievement tests.

Six of the 14 peer-reviewed studies were cross-sectional descriptive, seven were cross-sectional explanatory in nature, and one was a continuous baseline probe design. Non-experimental explanatory research generally develops or tests a theory about a phenomenon or tries to identify the causal factors (Johnson 2001). In descriptive non-experimental research, researchers primarily describe the phenomenon or document the characteristics of the phenomenon (Johnson 2001). There was a definite positive difference in achievement for the homeschooled students, compared to nonhomeschooled, in 11 of the 14 (78\%) peer-reviewed studies. The review also considered two state-government-provided data sets of achievement scores, and both revealed higher-than-average academic achievement test scores for the home educated.

A few researchers (e.g., McCracken \& Coleman, 2020) have implied or stated that they were studying the academic achievement of the homeschooled when, in fact, they were studying students in government-controlled state- 
run schooling at home. Such studies likely add to the research base and debate surrounding whether students in conventional public institutional schools or public distance, virtual, blended, online, correspondence, or public charter schools are better off than one another academically but they do almost nothing to inform discussions about homeschooling.

\section{Social, emotional, and psychological development}

One of the most common questions asked about homeschooling is, What about socialization? About 6 generations of people in most generations have only experienced institutionalized schooling so they do not understand how life was when home-based education was the norm for millennia. People wonder, if home-educated children are not with same-age peers for seven hours per day five days per week, how will they learn sound social skills and become sociable adults? The question presumes weekly day-long age segregation is necessary for sound social and emotional development. Many studies have addressed this topic.

Several early studies simply described the various social activities in which homeschool children and families participated (Delahooke, 1986; Ray, 1997). Investigators found that the large majority of the children were engaged in social activities with persons outside their families and regularly engaged in happenings such as organized group sports, organized clubs (e.g., scouts), religious classes with other children (e.g., Sunday school), music classes, and play activities.

More recent studies have explored more deeply the social activities of students and explored to what extent homeschool students are acquiring healthy social skills compared to those in institutional schools. Hamlin (2019), for example, explored the acquisition of cultural capital in a nationally representative survey of American Households, including children's engagement in activities such as attending live artistic performances, visiting museums, galleries, zoos, and aquariums, and going to community and sporting events. He concluded that “... relative to public school families, homeschool families report statistically higher participation in cultural and family activities. While patterns observed in this study are only descriptive, overall evidence suggests that homeschool families may provide opportunities for their children to acquire cultural capital through greater participation in cultural and family activities" (p. 312).

Ray's (2017b) review of all peer-reviewed studies on the social develop- 
ment of home-educated children and adults covered 15 studies. "Thirteen of the $15(87 \%)$ showed clearly positive outcomes for the homeschooled compared to those in conventional schools. Two of those studies reported that some of the findings were more positive for homeschool students but some were more positive for institutional school students" (p. 9).

That which Medlin (2013) found in his survey of research appears to still be accurate today:

Are homeschooled children acquiring the "skills, behavior patterns, values, and motivations" they need to function competently as members of society ...? And the answer to that question, based on three decades of research on homeschooling, is clearly yes. Recent research ... gives every indication that the socialization experiences homeschooled children receive are more than adequate. In fact, some indicatorsquality of friendships during childhood, infrequency of behavior problems during adolescence, openness to new experiences in college, civic involvement in adulthood-suggest that the kind of socialization experiences homeschooled children receive may be more advantageous than those of children who attend conventional schools. (p. 293).

\section{Success in adulthood}

Overall, those who were home educated while growing up are typically doing better than others in adulthood. Eleven of the 16 (69\%) peer-reviewed studies on the success of the home educated into adulthood (including college) showed positive outcomes for the homeschooled compared to those who had attended institutional or conventional schools (Ray 2017b). The learner outcome dependent variables included constructs such as level of psychological depression, involvement in positions of leadership, conscientiousness, openness, and college final grade point average (GPA). One study found positive outcomes for conventional school students compared to homeschool students. Finally, four of the studies found no significant difference between those from homeschool backgrounds and the others from institutional school backgrounds.

Many parents, and policymakers, want to know how the home educated will fare in postsecondary education environments. Ray (2017b) addressed this to a degree. Nearly a decade ago, Gloeckner and Jones (2013) asked college admissions officers about the home educated compared to other students. "Approximately $56 \%$ of the admission officers expected homeschool 
graduates to be as successful as traditional high school graduates, and nearly $22 \%$ expected them to be more successful. Only two admission officers expected homeschooled graduates to be less successful than traditional high school graduates. Ten (18\%) admission officers did not have an opinion on the expected overall success rate of homeschooled graduates" (p. 318). Most admissions officers expected the homeschooled to earn first-year GPAs similar to students from conventional schools, but about one-fourth expected homeschool graduates to outperform institutional high school graduates. Gloeckner and Jones concluded the following:

This study reveals the tremendous shift, in recent years, in admission officers' attitudes toward and perceptions of the homeschooled graduate. More than $78 \%$ of surveyed admission officers indicated that they expect homeschool graduates to perform, overall, as well or better in their $1^{\text {st }}$ year of college than traditional high school graduates. (p. 321)

\section{Characteristics and limitations of research to date}

Most studies that have examined homeschool learner outcomes have been cross-sectional and descriptive, and not designed to identify causal factors (Johnson, 2001). The majority have not been explanatory. On the other hand, a slowly increasing number of investigations are of designs that have lent evidence of causation (Ray, 2017b).

\section{Is The Very Nature of Homeschooling Good For Students?}

Keeping in mind the nature and limitations of studies on homeschooling, it can be said that home education is consistently associated with positive outcomes compared to what is manifested by students in or who have graduated from institutional public (state, government) schools. Many want to know, then, why? What mechanisms might be responsible for the positive successes of the home educated?

Ray (1997) was one of the first to theorize about why the home educated do well academically in a book on his second large nationwide study of homeschooling in the United States. He suggested "... four elements that might explain the apparent learning success of the home educated and the lack of practically significant relationships between these students' academic achievement and the independent variables examined in this study and 
in other studies. These elements may be interrelated" (p. 92). The elements the researcher proposed were (a) value consistency, value communities, and social capital, (b) tutoring, (c) academic learning time, and (d) social interaction and distraction. He also postulated the possibility that the home-based education environment ameliorates the effect of variables that might typically be considered a detriment to students' academic achievement (e.g., low household income, low parental education level, certain minority status, parents not having formal training or state certification as teacher, a child not commencing formal education until later in age, or less government control and regulation of homeschooling).

A few years later, Ray (2000) elaborated on his theory. He explained that many things associated with higher academic achievement in institutional schools are systemically natural to homeschooling in a way that they are not in institutional schools. Ray noted that homeschooling is not institutional school but that some of the elements associated with or causing better achievement in conventional schools might be transferable in terms of effect to any educational setting, including parent-led home-based education. His list of systemic features that might positively enhance achievement in parent-led home-based education compared to institutional classroom schooling included (a) more value consistency, value communities, and social capital, (b) smaller class size and more tutoring, (c) more individualization per student and more teaching flexibility during any given day, week, or month, (d) more academic learning time and academic engaged time, (e) more positive social interactions, cooperative learning, and age integration, (f) higher expectations of students, (g) higher levels of human capital, (h) and more parental involvement. Ray was not arguing that all homeschool families have or enact all of these variables but that they are more naturally and easily present in or amenable to a homeschool environment than to an institutional classroom setting.

A decade later, Murphy (2012) pulled together about 30 years of research on homeschooling to offer the reader a well-reasoned "speculative" model regarding “... what might explain the positive effects of homeschools on the academic and social learning of children" (p. 160) (and, see, Murphy 2014). He postulated three main variables in his theory of action. "If there is a beginning point in the logic of action for homeschooling's impact, it is most likely parental involvement ... It is also the keystone variable in the success algorithm. It includes the massive amounts of time and energy that parents invest in the education of their children ..." (p. 155). Murphy's second plank in his theory of action is "instructional program." He pointed out the while 
some critics of homeschooling are concerned that parents are not statecertified teachers, it appears they consistently offer their children one-onone instruction, low student-to-teacher ratios, effective use of time, more academic learning time, " ... a high degree of customization of learning experiences” (p. 157-158), considerable flexibility, more meaningful feedback between teacher and student, more extensive two-way dialogue between adults and children, an environment in which it is "... more difficult for a child to coast or hide in the crowd ..." and "...easier for parents to teach using direct (authentic) experiences" (p. 159), and an execution of homeschooling as “... a good way to encourage student ownership of learning ...” (p. 159).

Murphy's (2012) theory was completed with his third and final plank, the "learning environment." He reported that research literature suggests that home-educated children find themselves in "... more productive learning environments than those often found in the average public school ..., "... a climate that is safe and orderly, a nonthreatening culture in which the academic work of school can unfold ...," and "... the elimination of the negative peer culture sometimes seen in conventional schools ..." (p. 159). Murphy held, regarding the homeschool environment, that " $\ldots$ one often finds a supportive culture that grows from committed families and loving parents ..." (p. 159). Finally, in the third plank, the scholar's synthesis noted that “... a positive learning environment is made possible by the nurturing relationships that seem to be more easily forged in homeschools. .... The key here is the development in homeschools of a highly personalized climate in which the child is known, cared for, and respected more deeply than is possible in models of collective schooling ...” (p. 160).

Explanations regarding the cause of the relative success of homeschoolers, if they are in fact doing as well or better than their institutional school peers, are still speculative. One hypothesis is that if all background demographic variables (e.g., household income, parent education level, student and parent ethnicity, money spent on schooling, student learning disabilities/limitations, state teacher licensing status of the teachers/parents) were carefully controlled in a non-experimental explanatory study that tries to identify the causal factors (Johnson, 2001), then perhaps the home educated would perform no better than government conventional school students in terms of academic achievement, social and emotional development, or success into adulthood. This might be true. If such a study were to turn out this way with no statistically significant differences, then the "null findings" would, however, still be of notable practical significance (Kraft, 2020). As an example, consider the academic achievement of the homeschooled. No 
difference in achievement would mean that despite the fact that the public school students had state-certified teachers, university school of educationtrained teachers, expert-designed curriculum materials, six to eight hours per day with similar-age peers, millions of dollars of tax-funded research and development by university education professors, and $\$ 15,000$ per student per year of tax dollars (plus taxes for capital expenditures) from the citizens (National Education Association, 2020), public school students performed no better on standardized achievement tests than homeschool students. One might then wonder what was the value of all of these supposed beneficial inputs that are had by public school students.

\section{Should Professional Educators Promote or Learn From Homeschooling?}

To date, there is no body of empirical evidence that homeschooling needs state controls (regulation) laid upon it. Further, if parent-led home-based education is consistently associated with benefits for students, as the current body of research suggests, should professional educators be promoting the practice? The simple answer is that educators should be promoting anything that is good for children's academic achievement, social and emotional development, and success into adulthood. Forty years of research show that homeschooling is typically better, if there is any difference, for children and adolescents than is government public institutional schooling. If this is true, then homeschooling should be promoted. No complicated argument is needed.

\section{Why Do Some Educators or Scholars Oppose Homeschooling?}

One could argue that promoters of homeschooling are just political or philosophical advocates of homeschooling but such an argument is moot. Those who promote homeschooling - whether professional educators, policymakers, lay parents, religious or non-religious leaders - are promoting pedagogical and family-life practices that benefit children. If the elements that are naturally systemic to homeschooling (as described above; e.g., high parental involvement, customization and individualization of curriculum and pedagogical approach for each student, high levels of social capital, safe learning environment, flexibility, small class size, mastery learning, much interaction between adults and children, plenty of time for reading) are good for students, then homeschooling should be promoted. 
If homeschooling is statistically associated with more positive outcomes than is conventional institutional public schooling, then why would professional educators not promote this educational approach for children and adolescents? A few reasons that appear in scholarly literature help with the answer to this question.

Ray (2013) laid out four classes of negativity toward home-based education. The first has been a group of scholars who "... claim, in one way or another, that parent-led home-based education is bad for the collective good, the common good, or society as a whole" (p. 330). Lubienski (2000), for example, argued that homeschool parents are essentially selfish and their home education of their children "... denies democratic accountability and disenfranchises the community from its legitimate interest in education" (p. 229). Apple (2006) argued that black parents homeschooling their children is bad for society because the choice to home educate one's children "... cannot build momentum for the large scale transformations that are necessary" in society.

The second form of negativity toward home education is writers who claim that homeschooling is that motivated by a fear of being in contact with people who are not like oneself. Apple (2005), for example, claimed that many homeschool parents are afraid of allowing their children to associate with "the Other," people different from themselves.

The third class of negativity opines that homeschool parents might do some direct harm to their children (e.g., academically, emotionally). West (2009) held that “... public and private schools provide for many children ... a safe haven in which they are both regarded and respected independently and individually" in a way that homeschool environments would not. West also argued that adults who were homeschooled, especially those of Christian parents, cannot think for themselves and are politically engaged; she sees this as a harm to people and society. Further, West argued that the home educated grow up to be ethically servile. As another example, Fineman (2009) and Fineman and Shepherd (2016) argue that only the state, not parents, can assure that children's best interests are met.

And the fourth form of negativity toward home-based education is expressed by some academics or policymakers who advocate that homeschooling must simply be controlled more by the state and less by the parents, but they generally do not specify exactly how much the state should control the child's education. Their idea is that the government must control private 
education to ensure that the children's educational and other interests are honored and fulfilled (e.g., Bartholet, 2020; Kunzman, 2009).

None of the scholars in the abovementioned categories of negativity toward homeschooling provided substantive evidence-based bodies of research or statistics to support their claims. Their arguments (e.g., Bartholet, 2020) are essentially philosophically, religiously, politically, or theoretically based (Wolf, Lee, \& Watson, 2020; Ray, 2020). They tend toward the presupposition that the state must control all forms of education or schooling, including all forms of non-government schooling; some call for banning all private education (e.g., Fineman, 2009).

At the same time, West (2009) could have some empirical basis for her concerns that adults who were home educated might have worldviews more similar to their parents than those who are educated in state (government) schools. Ray $(2004,2015)$ found that children who were home educated have, at a very high rate, belief systems that are similar to those of their parents. West was concerned that adults who were home educated would have worldviews different from West's or those promulgated in state-run institutional schools. And this would be a reason why West would not promote homeschooling.

\section{Should Some Families Not Engage in Home Education?}

Four decades of research show that a wide diversity of families can be successful at homeschooling (see reviews of research cited above). On average, homeschool children in families of low income fare better than their counterparts in institutional public schools. On average, homeschool children with parents of relatively low formal education levels fare better than their counterparts in institutional public schools. On average, home-educated children of ethnic minorities fare better than their counterparts in institutional public schools. On average, homeschool children whose parents have never been state-certified teachers fare as well as homeschool children whose parents have been state-certified teachers. Homeschool students in low-homeschool-regulation states perform as well academically as those in high-regulation states (Ray, 2010). As Rudner (1999) summarized his comprehensive nationwide study per the following:

"This study simply shows that those parents choosing to make a commitment to home schooling are able to provide a very successful academic environment" (p. 29). 
On the other hand, there are cases in which homeschooling would not be good for particular children. Homeschooling would not be a good fit for parents who do not want to work hard regarding the education of their children. Homeschooling is not done well when parents are slothful, unless they are willing to change and become industrious. Home education would not be a good fit for parents who want others, such as administrators and teachers in institutional schools, to have more say than the parents over the teaching, training, and indoctrination of their children. (All forms of schooling whether state schooling, private schooling, or homeschooling - involves the teaching, training, and indoctrination of children.) Homeschooling would not be a good idea for single parents who work outside the home who cannot find a way to engage other individual adults (e.g., friends, grandparents) or homeschool learning co-operatives to help with the education of their child. Likewise, homeschooling would not work well if all parents in the household needed to work outside the home and could not or would not find help with the homeschooling of their children. Home education would be bad in a situation in which parents want to do or do physical or sexual harm to their children. Homeschooling would be either sub-par or unhealthy in situations where children have serious needs for which parents cannot provide and when the parents are stubborn about getting help. Finally, home education would not be good for children if the parents were illiterate and were not able teach the fundamentals of reading, language, and mathematics and were not willing to study and learn enough to be able to do such teaching or get help with the instruction. As one might note, however, most of the aforementioned problematic scenarios could be resolved if the parents were willing to change or work hard for their children's education.

\section{Might Professional Educators Learn from the Modern Homeschooling Movement?}

Virtually all professional educators alive today grew up being institutionalized for schooling, for their education during ages 6 to 17. Institutional schooling is about all they know. As fish likely do not notice that they need water, most educators have little knowledge of and virtually no experience with what was the norm in humankind's history for thousands of years parent-led home-based education.

About 40 years ago, John Holt (1983), one of the first pioneers of the homeschooling and unschooling movement, wrote the seminal article, "Schools and Home Schoolers: A Fruitful Partnership," in an academic journal. His 
ideas about the potential benefits of the homeschool movement to institutional schooling were prescient and well worth repeating. "To give even as much as a single hour per day to silent reading (thus taking time away from reading instruction) would strike most educators as a dangerously radical experiment" (p. 393). He continued by listing several ways that public/government schools might change but pointing out it would be highly unlikely. "Not in the foreseeable future can we imagine a school district saying to its students, "You can read anything you like, and as much as you like, and we aren't going to grade you on it." ..... Nor are we likely to see large-scale and long-term research conducted to find out whether frequent testing actually helps children learn or only hinders them ...” (p. 393). After laying out a few more educational scenarios, Holt wrote about the only place where this kind of research would be likely to be carried out in a way to yield significant results.

That place is in the homes of families who are teaching their own children. This is the main reason why the home-schooling movement is so important to schools. It is - in effect, though certainly not by design - a laboratory for the intensive and long-range study of children's learning and of the ways in which friendly and concerned adults can help them learn. It is a research project, done at no cost, of a kind for which neither the public schools nor the government could afford to pay. (p. 393).

The modern homeschool movement is, essentially, a tax-free experiment (or a one-shot case study or an open laboratory) for any and all to examine and explore. As noted earlier in this article, there are many meaningful implications for education and policy even if homeschool students were found to perform no better than government-school students on standardized academic achievement tests. First, such tests were not developed and found to be valid and reliable for the wide variety of experiences or treatments that homeschool students have. Second, high test scores are not the main reason for why most children are homeschooled. And third, if more methodologically tight studies were to find that homeschool students' test scores were not significantly different from public or private school students' scores, then this might simply tell educators and policymakers that much of the licensure, standardization, legal and policy controls, tax dollars that are invested into government and private institutional schooling, and hegemony that professional educators and professors of education exert over the learning of children are not necessary. University professors of education and of educational psychology, state licensing agencies, teachers' unions, lawmak- 
ers, and others might find, if they were to attend to relevant research, that the most important elements of sound education are happening at a higher rate amongst the homeschool community than in conventional school systems.

This is not to say that the homeschooling community has nothing to learn or nothing on which to improve. On the contrary, they imply that they have plenty to learn. In the United States, for example, there are dozens of home-education conferences provided annually by statewide homeschool organizations across the 50 states where parents take courses, learn new concepts, study worldview, and are lectured on learning styles and special needs children. Both homeschool parents and large curriculum companies produce and are constantly improving their products and services. And homeschool parents regular and as a matter of course gather, both in person and online, to discuss trials, tribulations, and successes with one another, always looking for ways to help others and improve their own practice as home educators.

\section{Future Research and Concluding Comments}

Parent-directed, family-based and home-based private education homeschooling is an historical and age-old way to educate the next generation of humans. An increasingly greater diversity of parents and children are making proactive choices to participate in home education rather than government-run schooling and institutional private schooling. Empirical evidence firmly shows that there are generally positive student outcomes associated with homeschooling as compared to conventional institutional schooling. Finally, if educational theoreticians and practitioners and advocates of institutional schooling would pay heed to the flexibility, nimbleness, adaptability, customization, child-friendly traits, family-friendly environs, and freedom space of homeschooling, teaching and learning to the benefit of all children around the globe would be advanced faster than might otherwise have been imagined.

\section{References}

Barclay, W. (1959). Train up a child: Educational ideals in the ancient world. Philadelphia, PA: The Westminster Press.

Bartholet, E. (2020). Homeschooling: Parent rights absolutism vs. child rights to education and protection, Arizona Law Review, 62(1) (2020), retrieved April 30, 2020 from https://arizonalawreview.org/homeschooling-parent-rights-absolutism-vs-child-rights-to-education-protection/ 
Budajczak, M. (2020). Personal communication, October 6, 2020. Marek Budajczak, $\mathrm{PhD}$, is a professor University of Adam Mickiewicz and president of Instytut Educatio Domestica, both in Poland.

CBS News. (2020). Millions of kids around the world adjust to school in the coronavirus era. Retrieved October 8, 2020 from https://www.cbsnews.com/news/ coronavirus-school-reopen-millions-children-europe-asia-return-covid-guidlines-2020-05-21/

Delahooke, M. M. (1986). Home educated children's social/emotional adjustment and academic achievement: A comparative study. Doctoral (Ph.D.) dissertation, California School of Professional Psychology, Los Angeles, CA.

Fields-Smith, C., \& Kisura, M. W. (2013) Resisting the status quo: The narratives of Black homeschoolers in Metro-Atlanta and Metro-DC. Peabody Journal of Education, 88(3), 265-283.

Fineman, M. A. (2009). Taking children's interests seriously. In M. A. Fineman, \& K. Worthington (Eds.), What is right for children? The competing paradigms of religion and human rights, (pp. 229-37). Burlington, VT: Ashgate Publishing Company.

Fineman, M., \& Shepherd, G. B. (2016). Homeschooling: Choosing parental rights over children's interests. University of Baltimore Law Review, 46(1), 57-106.

Gatto, J. T. (2001). The underground history of American education: A schoolteacher's intimate investigation into the problem of modern schooling. Oxford, NY: The Oxford Village Press.

Gloeckner, G. W., \& Jones, P. (2013). Reflections on a decade of changes in homeschooling and homeschooled into higher education. Peabody Journal of Education, 88(3), 309-323.

Hamlin, D. (2019) Do homeschooled students lack opportunities to acquire cultural capital? Evidence from a nationally representative survey of American households. Peabody Journal of Education, 94(3), 312-327.

Holt, J. C. (1983). Schools and home schoolers: A fruitful partnership. Phi Delta Kappan, 64, 391-394.

Home School Legal Defense Association. (2020). Mexico: Legal status and resources on homeschooling in Mexico. Retrieved October 7, 2020 from https://hslda.org/ post/mexico

Homeschoolingbackgrounder.com. (2020). What is homeschooling? Retrieved October 9, 2020 from www.homeschoolingbackgrounder.com

Johnson, B. (2001). Toward a new classification of nonexperimental quantitative research. Educational Researcher, 30(2), 3-13.

Kostov, V. Personal communication, October 8, 2002, with Viktor Kostov, Ph.D., lawyer for the Freedom for All, a human rights and homeschool defense group.

Knowles, J. G. (1988). Parents' rationales and teaching methods for home schooling: The role of biography. Education and Urban Society, 21(1), 69-84.

Kunzman, R. (2009). Understanding homeschooling: A better approach to regulation. Theory and Research in Education, 7(3), 311-330.

Kunzman, R., \& Gaither, M. (2020). Homeschooling: An updated comprehensive survey of the research. Other Education. The Journal of Educational Alternatives, 9(1), 253-336.

Kraft, M. A. (2020). Interpreting effect sizes of education interventions. Educational Researcher, 49(4), 241-253. Retrieved June 29, 2020 
Lubienski, C. (2000). Whither the common good? A critique of home schooling. Peabody Journal of Education, 75(1 \& 2), 207-232.

Mayberry, M.; Knowles, J. G.; Ray, B. D.; \& Marlow, S. (1995). Home schooling: Parents as educators. Newbury Park, CA: Corwin Press (of Sage Publ.).

McCracken, C., \& Coleman, R. (2020). A meaningful measure of homeschool academic achievement: Statistical analysis of standardized test performance in Alaska public correspondence schools. Other Education: The Journal of Educational Alternatives, 9(1), 207-252.

Medlin, R. G. (2013). Homeschooling and the question of socialization revisited. Peabody Journal of Education, 88(3), 284-297.

Murphy, J. (2012). Homeschooling in America: Capturing and assessing the movement. Thousand Oaks, CA: Corwin, a Sage Company.

Murphy, J. (2014). The social and educational outcomes of homeschooling. Sociological Spectrum: Mid-South Sociological Association, 34(3), 244-272.

National Education Association. (2020). 2020-2021 NEA resolutions. Washington, DC: Author. Retrieved September 28, 2020 from https://www.nea.org/sites/default/files/2020-09/NEA\%20Resolutions_2020-2021.pdf

New York Times. (2020). The freedom and fulfillment of home-schooling: Nine families shared with us why they chose to educate their children outside the traditional school system. Retrieved October 9, 2020 from https://www.nytimes. com/2020/08/18/parenting/homeschool-families.html

Ray, B. D. (1990). A nationwide study of home education: Family characteristics, legal matters, and student achievement. Salem, OR: National Home Education Research Institute

Ray, B. D. (1997). Strengths of their own-Home schoolers across America: Academic achievement, family characteristics, and longitudinal traits. Salem, OR: National Home Education Research Institute.

Ray, B. D. (2000). Home schooling: The ameliorator of negative influences on learning? Peabody Journal of Education, 75(1\&2), 71-106.

Ray, Brian D. (2004). Home educated and now adults: Their community and civic involvement, views about homeschooling, and other traits. Salem, OR: National Home Education Research Institute, www.nheri.org.

Ray, Brian D. (2010). Academic achievement and demographic traits of homeschool students: A nationwide study. Academic Leadership Journal, 8(1).

Ray, B. D. (2013). Homeschooling associated with beneficial learner and societal outcomes but educators do not promote it. Peabody Journal of Education, 88(3), 324-341.

Ray, Brian D. (2015). Gen2 Survey: A spiritual and educational survey on Christian millennials. Salem, Oregon: National Home Education Research Institute

Ray, B. D. (2017a). A review of research on Homeschooling and what might educators learn?" Pro-Posições, 28 (2).

B. D. (2017b). A systematic review of the empirical research on selected aspects of homeschooling as a school choice. Journal of School Choice: International Research and Reform, 11 (4): 604-621.

Ray, B. D. (2020). What is "good" research? A homeschool researcher responds to Harvard professor's criticism: Research methods 101. Retrieved October 9, 2020 from https://www.nheri.org/what-is-good-research-a-homeschool-researcher-responds-to-harvard-professors-criticism/ 
Resetar, M. A. (1990). An exploratory study of the rationales parents have for home schooling. Home School Researcher, 6(2), 1-7.

Rudner, L. M. (1999). Scholastic achievement and demographic characteristics of home

school students in 1998. Educational Policy Analysis Archives, 7(8). Retrieved October 10,2016

from http:/ / epaa.asu.edu/ojs/article/viewFile/543/666

Solorzano, L. (1985, August 19). Teaching kids at home stirs new uproar. U. S. News and World Report, p. 59.

Stock, P. (2020). Personal communication, October 6, 2020. Peter Stock is president of the Home School Legal Defence Association of Canada.

UNICEF. (2020). COVID-19: At least a third of the world's schoolchildren unable to access remote learning during school closures, new report says. Retrieved October 8, 2020 from https://www.unicef.org/press-releases/covid-19-least-third-worlds-schoolchildren-unable-access-remote-learning-during

United States Department of Education. 2001. Homeschooling in the United States: 1999. Retrieved June 11, 2020 from https://nces.ed.gov/pubsearch/pubsinfo. asp?pubid=2001033

United States Department of Education. 2010 Digest of Education Statistics, 2009. Washington, DC: National Center for Education Statistics. Retrieved June 26, 2020 from https://nces.ed.gov/pubs2010/2010013.pdf

United States Department of Education. 2019. Homeschooling in the United States: Results from the 2012 and 2016 Parent and Family Involvement Survey (PFI-NHES: 2012 and 2016). Retrieved January 6, 2020 from https://nces.ed.gov/ pubs2020/2020001.pdf

Van Galen, J. A. (1991). Ideologues and pedagogues: Parents who teach their children at home. In J. A. Van Galen, \& Mary A. Pitman (Eds.), Home schooling: Political, historical, and pedagogical perspectives (pp. 63-76). Norwood, NJ: Ablex Publishing Corporation.

Wartes, J. (1987). Report from the 1986 home school testing and other descriptive information about Washington's home schoolers: a summary. Home School Researcher, 3(1), 1-4.

Wikipedia. (2020). Homeschooling international status and statistics. Retrieved October 7, 2020 from https://en.wikipedia.org/wiki/Homeschooling_international_ status_and_statistics\#cite_ref-32

Wolf, P. J.; Lee, M. H.; \& Watson, A. (2020). Harvard law professor's attack on homeschooling is a flawed failure. And terribly timed, too. Education Next. Retrieved October 9, 2020 from https://www.educationnext.org/harvard-law-professors-attack-on-homeschooling-flawed-failure-terribly-timed/

\section{Author:}

Brian Ray, Ph.D.

National Home Education Research Institute

PO Box 13939

Salem OR 97309

USA

Email: bray@nheri.org 